\title{
Information and Communications Technology: Plugging Ontario Higher Education into the Knowledge Society
}

\author{
Jamie-Lynn Magnusson \\ Ontario Institute for Studies in Education, Canada
}

\section{ABSTRACT}

In this article I examine information and communications technology (ICT) in the context of changes to higher education. My analysis uses Ontario as a case study to illustrate that ICT and the knowledge society discourse is not about technological innovation per se. Rather the discourse legitimates neoliberal reforms to the higher education sector to lay the ground for participation in international markets. That is, these reforms enable privatization of higher education in keeping with pressures exerted by the World Trade Organization (WTO) and the General Agreement on Trade and Services (GATS). The case of Ontario is interesting because of the strategies used to "sell" massive neoliberal reforms to a public that has been, generally speaking, quite protective of its public services. The strategies and mechanisms used to "plug Ontario into the Knowledge Society" reveal how GATS works in local jurisdictions, and contributes to the study of how education within social welfare states comes to take on market characteristics.

Key words: Information technology, Higher education, Knowledge society, Neoliberal economics, World Bank, GATS, WTO

\section{RESUMEN}

En este artículo examino las tecnologías de la información y la comunicación (TIC) en el contexto de los cambios de la educación superior. Mi análisis se centra en Ontario, como estudio de caso para ilustrar cómo el discurso en torno a las TIC y la sociedad del conocimiento, no se refiere a la innovación tecnológica en sí misma. Más bien, el discurso legitima las reformas neoliberales en el sector de la educación superior para asentar las bases de la participación en los mercados internacionales. Es decir, estas reformas posibilitan la privatización de la educación superior en consonancia con las presiones ejercidas por la Organización Mundial del Comercio (OMC) y el Acuerdo General sobre el Comercio de Servicios (AGCS). El caso de Ontario es interesante debido a las estrategias usadas "para vender" masivas reformas neoliberales a un público que ha sido, en términos generales, muy celoso de sus servicios públicos. Las estrategias y los mecanismos usados "para conectar Ontario en la sociedad del conocimiento" revelan cómo funciona el AGCS a escala local, y da pistas para estudiar el modo en que la educación llega a adquirir las características del mercado dentro de los estados sociales del bienestar.

Descriptores: Información superior. Neuvas technologias de la informacion y de la communicacion. Neoliberales. La Sociedad del comocumento. 


\section{RÉSUMÉ}

Dans cet article, j'examine la technologie de l'information et de la communication (ITC-ICT) dans le contexte des changements à l'enseignement supérieur. Mon analyse utilise l'Ontario comme étude de cas pour demontrer que le discours de l'ITC et de la Société du savoir n'est pas au sujet des innovations technologiques en soi. Mais bien plutôt, ce discours légitime les réformes néolibérales dans le secteur de l'enseignement universitaire, afin de préparer le terrain pour la participation aux marchés mondiaux. C'est-à-dire, ces réformes facilitent la privatisation de l'enseignement supérieur selon les pressions employées par l'Organisation mondiale du commerce (WTO) et le GATS. Le cas de l'Ontario est intéressant à cause des stratégies utilisées pour faire accepter des réformes néolibérales massives à un public qui, en général, a été plutôt protecteur en ce qui concerne ses services publics. Les stratégies et les mécanismes utilisés afin de "brancher l'Ontario sur la Société du savoir » démontrent comment le GATS fonctionne dans les juridictions locales, et contribue à étudier comment l'enseignement au sein de l' État-providence en vient à revêtir les caractéristiques du marché.

Motes-Clés: La technologie de l'information (l'informatique, IT). L'enseignement supérieur. La Société du savoir. L'économie politique néo-libérale. La Banque Mondiale. L'accord général sur le commerce et les services (AGCS-GATS). L'organisation du commerce mondial (OMC-WTO)

"The knowledge society" is a term from an emergent discourse inciting radical reforms to higher education systems. (1) The report submitted by the Minister for Information Technology IT Advisory Group to the New Zealand Government (1999) is a kind of poster-perfect example illustrating this "knowledge society" rhetoric. According to this report, higher education must adapt to the age of digitization in which the numbers of internet users continue to grow, creating new markets for goods and services. Accordingly, higher education is viewed as an integral aspect of a new economy, signaling the transition from "the industrial age" to "the information age," wherein education and higher education play an important economic role. According to the United Kingdom Department of Trade and Industry "a knowledge-driven economy is one in which the generation and exploitation of knowledge play the predominant part in the creation of wealth." (Cited in New Zealand Ministry of Economic Development document) The new economy is predicated on an emergent "knowledge society" which in turn requires wedding information technology with educational reforms.

Glen Rikowski (2002) presents an excellent overview and critique of this neoliberal vision (2), analyzing the role of the World Trade Organization and in particular the General Agreement on Trade in Services (GATS). Similarly, others have developed excellent analyses that move beyond critiquing the knowledge society rhetoric in a general way to revealing how GATS, as applied to education reform, is taken up as specific local practice in particular jurisdictions. As Rikowski suggests, these kinds of analyses are necessary in order to reveal what he refers to as "the national faces of GATS". He calls for progressive education researchers to uncover and critique the precise mechanisms by which nation states collude with the WTO agenda to enable privatization of public services, which is the backdrop to education reform following the "knowledge society" platform. Using the UK as an example, Rikowski suggests that governments are unlikely to develop legislation that clearly derives from GATS because it would invite public backlash. Citing Hatcher (2001), Rikowski explains that "each step in the business takeover of public services has to be prepared ideologically. The public needs to be taken along with the 
GATS process, and any anti-GATS revolts stifled." $(2002,7)$. In the case of higher education, the discourse of the knowledge society and the urgency to get on board before it is too late is one such ideology. But the ways in which the public is prepared are multifarious, as are the mechanisms that enable a neoliberal framework for educational reform. Moreover, most educational research is complicit in this process, for example by setting up the evaluation systems and developing the new research programs of learning and pedagogy that support the knowledge society discourse (e.g., life-long learning, learning organizations, and such). Therefore, the call to engage critically with these discourses and to examine the "faces of GATS" is crucial to a democratic discussion and debate.

In this paper I respond to the call to analyze the national faces of GATS by examining recent reforms to the Ontario higher education system. As I explain later, in Canada the national faces of GATS are best revealed by studying individual provinces in that education is governed under provincial rather than federal jurisdiction. The Ontario case, I will argue, is interesting because, in spite of its obvious neoliberal characteristics, the blueprint for the reforms, derived from a specially commissioned report, has met with considerable public approval. Moreover, the initial implementation of the blueprint by the provincial Liberal government has likewise been embraced by the public. The case of Ontario can be used to examine the ways in which local governments use progressivist discourse (e.g., knowledge society discourse) to win public favor in order to implement quite radical neoliberal reforms.

The thesis of the paper is that information and communications technology (ICT) is changing the social organization of higher education in that it is embedded within government policy woven through the knowledge society discourse. The knowledge society discourse supports a neoliberal "reform" of the higher education system, undermining the public framework that has been strong in the Canadian provincial systems, including the province of Ontario. (3) I will show how knowledge society discourse, which argues that a new economics based on digitized knowledge and communications is on the horizon, shifts an understanding of education as a public good to an understanding of education as a privatized global business. Ontario represents an excellent case study of a higher education system undergoing a massive change from a social welfare public system to a system oriented to international market dynamics.

\section{Ontario Plugs into the Knowledge Society}

In Canada, individual provinces hold jurisdictional control over public services such as health and education. In an important sense, then, the kind of analysis that reveals specific strategies and mechanisms of neoliberal reform, and resistance to these reforms, needs to be undertaken at the level of provincial government. To the extent that Ontario's system of higher education has been described elsewhere, I will focus the discussion in this paper on the most current developments. Although Ontario's system will be the focus, it is important to understand that changes within this province represents a local response to federal expectations as outlined by the Council of Ministers of Education (Canada) report "Public Expectations of Postsecondary Education in 
Canada." (1999) As Kachur points out "the CMEC attempts to formulate answers to two political questions. 1) How can post-secondary educational institutions respond to cultural diversity and occupational demands while adapting to reduced government funding? 2) How can Canadians develop a national education strategy in light of provincial control of education and forces for a continental integration with the United States?" $(2004,8)$ In his analysis, Kachur provides an excellent overview of the ways in which this agenda corresponds with organizations such as the Organization for Economic Cooperation and Development (OECD) in the context of emerging market agreements in education through international trade agreements. The recent moves to reform Ontario's higher education system, then, achieves an articulation of this particular province with these broader networks.

Ontario moved swiftly to adopt the "knowledge society" discourse and in June 2000 established the Ontario Knowledge Network for Learning (OKNL) which is an office of the Ministry of Education; the Ministry of Training, Colleges and Universities; and the Community Services I and IT Cluster. The overview on the OKNL website is much like the report to the New Zealand government, discussed earlier:

There is no question about it: the knowledge society and economy have arrived. Computers have made their way into every aspect of our culture and nowhere is this more evident than in Ontario's schools. More then ever, information and communications technology (ICT) continues to change how, when, what, and where students learn. The integration of education and technology is crucial to the success of Ontario's present and future learners.... OKNL is working to help students develop the technology skills they need to compete successfully in the global economy and to take full part in the social and cultural life of our province, our country, and our world."

The goals of the OKNL are listed as follows:

1. All learners will have access to ICT-enhanced education.

2. Educators will have the knowledge and skills they need to integrate ICT into their teaching with confidence.

3. Learners, educators, administrators, and support staff across the province will have equitable access to ICT tools and resources.

4. Ontario will become a world leader in research and development in ICT-enhanced education.

5. Education-business partnerships will be formed to support ICT-enhanced education.

6. ICT will TRANSFORM relationships among learners, educators, businesses and community members across the province. (Note: emphasis is mine.)

The province of Ontario has adopted the knowledge society discourse as its official banner to justify specific kinds of reforms. In his analysis of this discourse, Michael Peters (2001) examines in detail the knowledge society's discourses and how these overlap with dominant discourses in economics, management, information technology, sociology, and futurology to construct a "knowledge economy" narrative. He suggests 
that, within this narrative the knowledge economy is constructed as different from the traditional economy in terms of "economics of abundance", "de-territorialization of the state", "the importance of local knowledge" and "investment in human capital." (Peters 2001, 7).

These characteristics together construct an economic narrative that goes roughly as follows. Traditional economics depend on resources that are limited, especially natural resources, and human labor. However, knowledge and information do not become depleted when used and can be used over and over again, shared, and in fact can grow through networking. Due to communications technologies, the effect of location and human limitations collapses, therefore offering the possibility of round-the-clock operations that extend globally through the construction of virtual markets. This has the effect of "de-territorializing the state in terms of laws governing trade and trade barriers and taxes, which become exceedingly difficult to apply on a national basis." As Peters further explains "pricing and value depends heavily on context, as the same information knowledge can have vastly different value for different people at different times." Finally, "human capital (i.e., competencies) is of key value in a knowledge based economy; knowledge based companies seek knowledge locked into systems or processes rather than in workers, because of its higher inherent value.” (Peters 2001, 8)

Peter's use of the term "hyperdiscourse" to describe this narrative is fitting in that, as Baudrillard suggests in his description of third order simulacra, information displaces the machine as the basic mode of production, and we are left with merely simulations of reality or "hyperreality".

I would like here to examine three kinds of criticism inherent in Peter's analysis of knowledge society discourse. First, the discourse blurs the distinction between "knowledge economy" and "knowledge society". In other words, "society" is collapsed into "economics", and, in particular, a very specific kind of economics, namely neoliberal capitalism. Rikowski uses the term "edubusiness" which captures this dynamic very nicely. (2002) Second, this linguistic game succeeds in constructing a very narrow understanding of "knowledge" that is instrumentalist in the sense of equating "knowledge" with "information," thereby achieving a discursive shift in how we understand intellectual culture. Third, as Peters points out, the discourses of futurology, which speculate on the knowledge society and its future implications, are ahistorical. That is, futurology discourses have been defining features of modernity and construct imaginaries that cannot be extricated from their capitalist histories. An important question concerning the knowledge society discourse, then, is whether "knowledge" can be separated from "capital."

\section{The Knowledge Society and Imperative for Higher Education Reform}

Across all Canadian provinces, higher education, much like healthcare and other social welfare services, evolved as a public entity woven through the social welfare state (Magnusson 2000). At the height of the social welfare state students paid minimal tuition, and those who could not afford the costs of tuition had access to financial aid. Simi- 
larly, rural students who could not afford the cost of relocation to a nearby city could access financial assistance. The diversity between institutions, especially the universities, has been minimal, a feature which ensures that students anywhere in Canada have access to the same quality of postsecondary education regardless of their province of origin or class origins. For this reason, students overwhelmingly have tended to attend the university closest to their family homes. Moreover, there is no financial advantage to attending a more distant university in the sense that a prestige differentiation between, say, a University of Saskatchewan degree versus a University of Alberta degree has not really existed.

Similarly, in the province of Ontario higher education has been largely a public entity. The primary dimension of difference within the provincial postsecondary system has been a pronounced differentiation between the community colleges and the universities. When this two-tiered system evolved under the Davis government in the 1960 s, care was taken to create the community colleges as two year "terminal" institutions that did not have degree granting status nor any transferability function. That is, students could not transfer from community colleges to universities. More recently, transfer arrangements are being negotiated between certain college programs and universities, and certain colleges have sought degree-granting status. The two-tiered feature of Ontario's postsecondary system is an obvious organizer of class relations within the province, and these relations are further organized in terms of gender and race. Within each of the sectors, however, there is little differentiation in terms of "prestige"; and within the university sector little differentiation is made between, for example, a McMaster University degree compared to a University of Western Ontario degree. Overall, the public framework for postsecondary education within this province has been strong. Access within the overall system is slightly above $50 \%$; there is virtually no prestige factor in terms of recognizing one degree as superior to another degree; tuition across institutions within each sector has been comparable. Although the system was not a perfect model of public accessibility (e.g., class or race relations organized through the two-tiered system), it nevertheless has been fairly good (e.g., regulated tuition and fairly standardized quality of education).

Becoming a participant in the knowledge society requires the restructuring of education, including higher education. Goals 5 and 6 of the Ontario Knowledge Network for Learning signal an impending shift toward the expansion of business into education:

5) Education-business partnerships will be formed to support ICT-enhanced education, and

6) ICT will transform relationships among learners, educators, businesses, and community members across the province. (OKNL)

The wording of these goals suggest that the kinds of changes being heralded are those supporting restructuring within a neoliberal paradigm with a strong imperative to privatize public services, including education. This imperative is backed by the WTO and GATS. (de Siqueira 2005) 
Recently, using precisely this protectionist platform, public opinion of the need to protect the public infrastructure of services such as healthcare and education has been strong as is evident by the election of the Liberal governments federally as well as provincially in Ontario. How then is it possible to advance the neoliberal agenda underlying the Knowledge Society economics, in light of the strong potential backlash?

\section{The Neoliberal Agenda}

Before answering the question above, I will outline how it is that the particular reform required in order to construct a Knowledge Society necessarily involves a neoliberal restructuring of public services. Moreover, although the mechanisms to achieve this restructuring differ from jurisdiction to jurisdiction, the overall effect is to change locally the social relations of education such that they, to use Dorothy Smith's language, map onto broader social relations of ruling. These broader relations of ruling, or the relations of capital, involve the neoliberal agenda achieved through what Kachur (2004) refers to as the nebuleuse, after $\operatorname{Cox}$ (2001). The nebuleuse is "something that has no fixed and authoritative institutional structure, but which has emerged out of discussion in bodies like the Trilateral Commission, the World Economic Forum meetings in Davos, the regular meetings of the central bankers of the OECD, IMF, World Bank, and WTO, and the G7 and G8 summit conferences and their preparatory meetings." (cited in Kachur 2004, 2)

Rikowski suggests that neoliberal globalisation relates in very specific ways to education. As he explains

The World Trade Organization (WTO) facilitates globalization through opening up all spheres of social life - including public services - to international capital. The WTO 'education agenda', therefore, is to facilitate the penetration of education services by corporate capital. The key WTO agreement for this purpose is the General Agreement on Trade in Services (GATS). This agreement incorporates the aim of unleashing progressive liberalisation of trade in services, including public services such as education. In the long term, no area of social life is exempt from these developments. $(2001,1)$

The concept that Kachur uses in his analysis of globalization and the education service industry in Canada, the nebuleuse, is very useful in that it constructs the process of globalization as emergent yet coordinated among particular players. According to Rikowski, governments or collective governmental agencies such as the EU have to manage the process of trade liberalization, including opening up public services to business takeover.

Delgado-Ramos and Saxe-Fernandez further explain:

According to Merrill Lynch analysts cited by Santos, capital growth in education has been exponential, showing one of the highest earning rates of the market; 1000 pounds invested in 1996 generated 3,405 pounds four years later. That is an increased value of $240 \%$, while the London stock exchange valorization rate 
accounted on the same period for $65 \%$. Other 2004 data indicate that, current commercialized education, incomplete as it is, already generates around 365 billion dollars in profits worldwide. It is indeed a juicy business if higher education is formally defined and treated as a "commodity" under the World Trade Organization's General Agreement on Trade and Services (GATS). (2005, 7-8)

DeSiqueira (2005) presents an excellent overview of how this process is coordinated among WTO/GATS and governments. (4) She explains that several groups have become interested in this market, but primarily from the businesses, including communication, computer science, services, and profit education management. Since this market is becoming restricted in the richest countries which already have a schooled population and a decreasing birthrate, developing countries are targeted by businesses seeking new markets in jurisdictions in which the majority of inhabitants are schoolaged. However, education has been established as a human and social entitlement regulated by the State, thereby limiting the commercial expansion of edubusiness in these jurisdictions. Commercial education traders can identify this limitation as a "barrier" to business, and seek to remove this "trade barrier". As de Sequeira notes: "As a result, there is growing pressure for education to be treated as a commodity, regulated by the market/commerce without interferences from the local regulations (barriers), but with increased possibility of reaping public funding." $(2005,3)$

The argument being made here with respect to the imperative to expand business into education can be generalized to all public services. For example Sexton states that "particularly under threat from GATS are public services - health care, education, energy, water, and sanitation.” (2001, 1). According to Rikowski (2002), the urgency to privatize public services is animated by two considerations. The first of these considerations is that home-grown business operators have to be nurtured so that when GATS becomes more powerful in terms of removing government restrictions, business operators in education, health, social services, and so on can compete successfully against foreign enterprises. The second consideration is that local governments are concerned that home-grown businesses that take over public services can develop into export earners. Education businesses can then export services to global markets and, in addition, offer education services locally, including university and college programs. Rikowski cites the example of one such U.K. business, Nord Anglia, which is exporting services to Russia and the Ukraine, as well as running schools within the U.K.

In terms of the imperative to privatize, Richard Hatcher (2000) makes a useful distinction between endogenous and exogenous privatization (e.g., Ball, 2004). Endogenous privatization involves reforming public sector delivery to cultivate market characteristics, thereby mimicking the private sector. Exogenous privatization involves allowing private providers to deliver public services. Both forms of reform are neoliberal in their characteristics and intent, and each have similar consequences in terms of practices and values, for example privileging market criteria over other kinds of social and community considerations in the delivery of services. Whereas endogenous privatization entails the state remaining in control of the service, endogenous privatization entails selling the service to a private provider. 
This distinction is particularly useful when analyzing the case of Ontario in that it is clear that the suggested reforms, which will be described below, alter the public framework of higher education by implementing specifically those changes that cultivate market characteristics. I suggest that they are of both the endogenous and exogenous kinds of reform, and that the overall strategy, as outlined above, is to nurture local providers who can compete against foreign competitors and to develop these service providers into export earners. Moreover, the movement toward cultivating Ontario as a "knowledge society" requires much more than an infrastructure of information and communication technologies. Contrary to knowledge society discourse, the technologies per se are not driving the changes. Rather, it entails a comprehensive reworking of the public framework of higher education. This reworking is now underway with the completion of a commissioned review by the Honourable Bob Rae, in conjunction with the implementation of the recommendations of the Rae Review by the Provincial Government under the Liberal leadership of Premier McGuinty. Moreover these changes correspond to many others coordinated at the national level, including the recent shift in the granting councils captured in the January 2005 report "From Granting Council to Knowledge: Renewing the Social Sciences and Humanities in Canada." Within this report the overview chapter is entitled "The Importance of Engagement and Impact in a Knowledge Society" (Social Sciences and Humanities Research Council of Canada, January, 2005). Similarly, Kachur provides an overview of the role of the Council of Ministers of Education of Canada (CMEC), and the Corporate Higher Education Forum (CHEF) in coordinating the activities of the university with the market. As Kachur wrote, "CMEC has been one of the strongest promoters of technology-mediated learning." (2004, 4) Therefore, the move toward being a knowledge society involves comprehensive reforms federally and provincially which are coordinated within the Canadian nebuleuse, which in turn is harmonized in terms of international nebuleuse, as described earlier.

\section{How Does Bob Rae's Review of Higher Education Comply with GATS?}

In the previous section I provided an overview of why "plugging into" the knowledge society necessarily entails neoliberal reforms to higher education, including endogenous and exogenous privatization. I now return to the question that I left dangling. That is, how will it be possible to advance the neoliberal agenda underlying knowledge society economics in light of the strong potential backlash from a public that is increasingly sensitive to the erosion of public health care and public education? As mentioned previously, both the federal and provincial Liberal parties are sensitive to public sentiment regarding public services, as was evident in their respective election platforms. At the moment, Ontario is led by the provincial Liberals under Premier McGuinty and the federal government is led by the national Liberals under Paul Martin. Both levels of parties won public favour for their protectionist platforms.

Rikowski (2002) believes that the public must be ideologically prepared for this kind of comprehensive change - otherwise they will resist. He further argues that for 
governments "the links between the GATS and the national enablers must remain an enigma. Such links must be denied or evaded, otherwise the full force of the WTO's impact on national life becomes apparent, leading to the liklihood of a significant national politics of resistance to the WTO in general and the GATS in particular." $(2002,1)$ Within Ontario governments which advocate the wholesale privatization of higher education would invite just such a backlash.

Part of the answer to this matter of how to avoid public backlash is that Ontario has officially adopted the knowledge society discourse, which is a powerful ideological tool. Further, as discussed earlier, it has created the Ontario Knowledge Network for Learning $(\mathrm{OKNL})$ organized through the primary Ministries dealing with education, higher education, and community, thereby institutionalizing a language and logic that articulates "knowledge" with "markets" and "economic abundance." The emotional valence of Knowledge Society discourse is one of urgency - "let's get on board before it's too late".

Most recently, the McGuinty government hatched a strategy to commission a comprehensive review of Ontario higher education by the former leader of the provincial New Democratic Party (NDP), Bob Rae. Within Canada, the NDP is backed by the labour unions and historically has been a key player in strengthening social welfare policies. The NDP has a firm commitment to interventionist economics and protectionist policies in an era of free trade, and, of the major parties in Canada, the NDP is the most left-leaning and is committed to socialist democratic perspectives.

Bob Rae's report, locally referred to as "the Rae Review," was submitted to the Liberal McGuinty government February, 2005. The report was intended to be completed in time for the Liberal government to present the Ontario budget which was announced May 11, 2005. The budget shows a strong commitment to implementing the recommendations from the Rae Review and has been marketed as the largest multiyear investment into higher education in 40 years or since the rapid expansion of the postsecondary sector in the 1960s. The 2005 Ontario Budget for higher education is introduced as follows: "The McGuinty government understands that, in today's knowledge economy, education is the prerequisite for prosperity." (www.ontariobudget.fin .gov.on.ca/bud05e/bke1.htm). The Budget further announces that "the McGuinty government's action plan for colleges, universities, and training, highlighted by a $\$ 6.2$ billion cumulative investment by $2009-10$. This investment includes an additional $\$ 683$ million in $2005-06$, rising to $\$ 1.6$ billion by 2009-10." Therefore the overall result of the Rae Review, as taken up by the McGinty government, appears as an almost unprecendented public investment into higher education. Moreover, this investment, according to the Rae Review, will benefit lower income families and populations that have historically seen low participation rates, including Aboriginal peoples, new Canadians, and youth from low income families.

Although it is too early to determine the extent to which the McGinty government will implement the full range of recommendations laid out by Rae, it is clear that there has been significant movement. The following represent the recommendations from the Rae Review that are particularly problematic in terms of neoliberal reforms commonly linked to Knowledge Society economic logic. 
First, although recommending a significant infusion of new public funding into Ontario higher education, Rae is clear that government should not increase funding to institutions in order to lower tuition fees, thereby making higher education more accessible for everyone. This recommendation is noteworthy in that the public framework for Canada's higher education, as described earlier, was achieved precisely through block transfer grants to the provinces, which in turn had a system of block transfer grants to postsecondary institutions. Although the details of funding differed somewhat from province to province, the net effect is that across all provinces, the State has been the main funding source, covering basic operating costs through a no-strings attached block funding arrangement. Tuition fees have been universally low across all provinces, and governments have imposed strict limitations on the amount of tuition that institutions can charge. In addition to offsetting the cost of tuition fees and regulating the fee structure, governments have had in place funding mechanisms such as student loans and student aid. For example, when I first attended university, I paid a tuition fee of $\$ 500$ for the year, and qualified for a student loan that I did not have to repay until I completed my higher education. No interest was charged on the loan until payment was initiated. Along with others from working class backgrounds, this public framework created the possibility for us to be the first generation in our families to attend university.

Rae is decisive in recommending against this kind of strategy to fund higher education. It argues that governments should not set tuition levels, but that "institutions must clearly retain ultimate responsibility for tuition levels of individual programs." $(2005,23)$. The argument continues, "the notion that higher education is some kind of nationalized industry, where the price of everything is set by central planners in an office at Queen's Park, is out of place in the modern world. We shall not achieve autonomy, flexibility, and competition within the system - all desirable goals - so long as all tuition decisions are made centrally." (2005, 23). In other words, the Review recommends deregulating tuition, in effect allowing individual institutions to establish the tuition level for programs according to what the market will bear.

The government's role, according to the Rae Review, should be in establishing a regulatory framework that ensures that institutions are accountable for "tangible quality improvements that students will see for increases in tuition, and adequate financial support for students in need." $(2005,23)$ In order to achieve this regulatory framework, a Council on Higher Education is to be established to "work with the sector and government in establishing targets and measures for improvement and report on performance and outcomes." $(2005,15)$ In the budget of the present Liberal government in Ontario, the quality control function of this proposed council is further reinforced by calling it the "Higher Education Quality Council of Ontario." In other words, the costs of higher education are being downloaded onto students, who are the customers or consumers of a service. Institutions are to be accountable to "students in need" by setting aside a percentage of the increased revenues from tuition fee increases to use for student financial need.. (5) At the same time, government's new role is to monitor the quality of higher education by setting up a centralized system of continuous quality control and by reporting on performance and outcomes. To buttress the 
validity of these recommendations, two other jurisdictions in North America, Alberta and Texas, are pointed to as having already moved in this direction. It seems that the report is modeling Ontario's higher education along the lines of some of the most politically conservative jurisdictions in North America that are noted for their neoconservative/neoliberal policies.

We have seen so far that the recommendations in the Rae Review involve a neoliberal reform using an endogenous strategy, that is, the recommendations rework an existing public sector to mimic the market characteristics of the private sector. However, the recommendations are sold to the public by emphasizing how they will increase public accessibility to postsecondary education and also increase public accountability. The strategy for increasing public accessibility while at the same time deregulating tuition fees involves up-front grants up to $\$ 6000$ to students from low income families, that is, family incomes below $\$ 22,615$ would benefit from the maximum grant, and family incomes at $\$ 35,000$ could be eligible for the minimum grant of $\$ 500$. . Postsecondary institutions that set tuition fees above $\$ 6000$ would be required to use a portion of their revenues to cover the tuition fees of students in financial need. Students receiving financial assistance from institutions would be those who, for example, attend a program charging $\$ 8000$, but who qualify for an up-front grant of $\$ 6000$. The institution would then provide the additional $\$ 2000$ to cover the shortfall.

To summarize, the Rae Review recommends that the government not provide increased monies to lower or regulate tuition fees. Rather, the provincial government's role is seen as regulating the quality of service being provided to students through the new Higher Education Quality Council. The lowest income students are to receive what is very similar to vouchers - an up-front grant to cover their tuition. Vouchers have been one kind of strategy used to achieve endogenous reforms to public services. Other students will pay their own fees, but will receive somewhat more assistance in the form student loans, for which a more forgiving payment structure than the current system is recommend. A further recommendation is that because the cost of living in Ontario is high, the federal government should be responsible for implementing a costof-living funding to Ontario students. Overall, these strategies constitute endogenous neoliberal reforms that have the effect of altering higher education from a public service to a service with market characteristics which therefore has the same consequences as exogenous neoliberal reforms. For example, as education becomes increasingly oriented to market dynamics, an erosion of the public and democratic framework takes place.

\section{Conclusion: "Plugging" Ontario Higher Education}

The article began by analyzing the corporate discourse and neoliberal intent inherent in the knowledge society discourse associated with ICT. Establishing the Ontario Knowledge Network for Learning (OKNL) was only one step along the way to plugging Ontario into the knowledge society. As argued earlier, further steps are required, which in the case of Ontario and most other Canadian provinces will be difficult. Canadians view their social welfare infrastructure with a certain degree of pride and have become protective of their public services. The Rae Review was a successful public relations 
strategy in this regard. As a former leader of the most left leaning of the three main provincial parties, Bob Rae and the McGuinty government sold a system of major neoliberal reforms to the public by cashing in on the NDP's reputation for social democratic policies. (7) Student organizations have not been fooled, and progressive faculty groups have not been fooled, and a segment of the public has not been fooled. Nonetheless, overall the local media attention in the major newspapers has been quite positive, and the public response to the McGuinty higher education budget has been favorable.

Following Rikowski's (2002) argument earlier, the two major considerations to reform education in this manner are, first, to nurture home-grown businesses, and, second, to cultivate export earners. The McGuinty strategy appears to be to implement endogenous neoliberal reforms to Ontario's higher education system in order to compete in the international market. The Rae Review is quite clear about this: "According to the Conference Board of Canada, global demand for international higher education is set to grow from 1.9 million international students today to 7.2 million international students by 2025." (2005, 58) In order to compete in this emerging global market the Review recommends that Ontario "pursue marketing efforts, jointly with the sector and the federal government, to ensure that Ontario remains an important "educational destination "for international students." $(2005,57)$ The Review further explains that

(o)ther jurisdictions have moved more quickly, with government leadership and funding at the national level, to create broader marketing and accessibility strategies to attract international students. The United States receives the largest share of the global total (30\%), followed by the United Kingdom and Germany (12\% each), Australia (10\%) and France (9\%). By contrast, Canada's total share of postsecondary international students is less than $1 \%$ (of which about $40 \%$ come to Ontario). (2005, 58)

The scenario above sounds as though Canada has missed the boat. What it doesn't report is Canada's high participation rate in postsecondary education and its equitable standards of quality across the country that are due to the strong public framework that has existed. Canada is ahead of the U.S. in these respects. Imagine the quality difference in university education between those who pay $\$ 6000$ a year in Canada compared to those who pay upwards of $\$ 35,000$ a year in the United States? Imagine the difference in career prospects, and the cultural capital associated with a degree from an expensive institution in the United States. In Canada this kind of tuition differential does not exist. However, the public needs to speak out loudly in order to protect what has been an excellent public system.

Rather than "plugging Ontario into the knowledge society", it appears that the McGuinty government, by implementing the Rae recommendations, intends to simply "plug Ontario" to an international market wherein higher education is shaped by market forces and decisions are made consistent with market interests. As Delgado-Ramos and Saxe-Fernandez (2005) point out in the case of Mexico, increasing public spending 
into an education sector that has been reshaped to have market characteristics, ends up benefiting corporate and not public interests. The Rae Review makes clear that the new Higher Education Quality Council is to track enrollment and other quality indicators in order to "tell us which way "customers" are going. This is a field in constant evolution." $(2005,17)$ The primary reason governments privatize certain services is precisely because the interests of the market contradict the interests of the public.

The argument presented here is that ICT and the Knowledge Society discourse is woven through neoliberal economics through and through. Ontario represents an interesting case to study for the ways in which the government has ideologically prepared the public for a massive neoliberal reform of a postsecondary system that has historically had a strong public framework with participation rates exceeding 50\%. Analyzing how these reforms have been marketed reveal yet another "face" of the General Agreement on Trade and Services.

\section{References}

Amin, S. 1997. Capitalism in the Age of Globalization. New Jersey: ZED.

Ball, S. 2004. Education 4 sale: The commodification of everything? Paper presented for the Kings Annual Education Lecture, University of London.

Chomsky, N. 1999. Profit Over People: Neoliberalism and the Global Order. London: Seven Stories Press.

Cox, R. W. 2002. The Political Economy of a Plural World. London \& New York: Routledge.

Delgado-Ramos, G. C., \& Saxe-Fernadez, J. 2005. The World Bank and the privatization of public education: A Mexican perspective. Journal for Critical Education Policy Studies 3. www.jceps.com.

Hatcher, R. 2001. Getting down to business: Schooling in the globalized economy. Education and Social Justice 3: 45-59.

Kachur, J. 2004. Globalization, the OECD, CMEC and the education service industry in Canada. Paper presented at the Socialist Studies Society meetings, Winnipeg, Canada.

Magnusson, J. 2000. Canadian higher education and citizenship in the context of state restructuring and globalization. Encounters on Education 1: 107-126.

Martinez, E., \& Garcia, A. What is neoliberalism: A brief definition for activists. http://www.corpwatch.org/article.php?id=376 (accessed September, 2005).

McChesney, R. W. 1998. Introduction. In Noam Chomsky 1999 Profit over people: Neoliberalism and the Global Order. London: Seven Stories Press.

New Zealand. Ministry of Economic Development. What is the Knowledge Society?

http://www.med.govt.nz/pbt/infotech/knowledge_economy/knowledge_economy04.html (accessed September 2005)

Ontario. Ministry of Finance. 2005 Ontatio Budget, Investing in People, Strengthening Our Economy. Toronto. Ministry of Finance, 2005.

Ontario. Ministry of Finance. The McGuinty Government Plan for Postsecondary Education, May 11, 2005, www.ontariobudget.fin.gov.on.ca/bud05e/bke1.htm September 2005)

Ontario Knowledge Network for Learning (OKNL) (http:/oknl.edu.gov.on.ca/eng/overview/default.asp (accessed September, 2005)

Peters, M. (2001). National education policy constructions of the "knowledge economy": Towards a critique. Journal of Educational Enquiry: 2.

Rae, B. (2005). Ontario: A leader in learning. Report and Recommendations, February.

Rikowski, G. (2002). Globalisation and education. A paper presented for the House of Lords Select Committee on Economic Affairs, Inquiry into the Global Economy. 
Social Sciences and Humanities Research Council of Canada. 2005. "From Granting Council to Knowledge: Renewing the Social Sciences and Humanities in Canada." Within this report the overview chapter is entitled "The Importance of Engagement and Impact in a Knowledge Society"

DeSequeira, A. (2005). The regulation of education through the WTO/GATS. Journal for Critical Education Policy Studies, 3, www.jceps.com.

Torfing, J. (2003). Discourse theory: It's empirical application and methodological selfreflection. http://www.diskurs.dk/arrangementer/DISCconf.pdf (accessed September, 2005).

\section{Endnotes}

1. The paper presents a critical analysis of "knowledge society discourse" along the lines of "discourse theory". According to Jacob Torfing (e.g., 2003), discourse theory has the following characteristics:

1. post-structuralist discourse theory is a tool for analyzing the more or less sedimented rules and meanings that condition the political construction of social, political, and cultural meanings and identities; 2. it builds on anti-essentialist ontology and argues with Derrida that there is no pregiven self determining essence that is capable of structuring the totality while itself escaping the process of structuration;

3. it is founded on an anti-foundational epistemology, and argues with Rorty that the world exists out there, but truth does not; 4 . discourse theory holds a relationalist, contextual and historicist view of identity formation; 5. it argues that at the bottom, the world does not consist of transparent and self-referential essences that are commonly blurred by distorting ideologies and opaque ideologies; rather at the bottom, we find an undecidable and dilemma-filled play of meaning that can only be arrested by ethicopolitical decisions that gives rise to contingent forms of discourse; 6. most importantly it urges us to shift our analytical focus from the positivist focus on observable facts, over the hermeneutic focus on deep meaning, to the discourse-theoretical focus on the historical conditions of possibility of meaning and action.

These characteristics outlined by Torfing are nested within a somewhat more elaborated summary of discourse theory can be found at the following website: http://www.diskurs.dk/arrangementer/DISCconf.pdf.

1. This explanation of neoliberalism is offered by Robert W. Chesney in his introduction to Chomsky's text "Profit Over People" (1999):

Neoliberalism is the defining political economic paradigm of our time - it refers to the policies and processes whereby a relative handful of private interests are permitted to control as much as possible of social life in order to maximize their personal profit. Associated initially with Reagan and Thatcher, for the past two decades neoliberalism has been the dominant global political economic trend adopted by the political parties of the traditional left as well as the right. These parties and the policies they enact represent the immediate interests of extremely wealthy investors and less than one thousand large corporations. (Chesney 1999: 7).

Chomsky relates neoliberalism to the Washington consensus:

The neoliberal Washington consensus is an array of market oriented principles designed by the government of the United States and the international financial institutions that it largely dominates, and implemented by them in various ways - for the more vulnerable societies, often as stringent structural adjustment programs. The basic rules, in brief, are: liberalize trade and finance, let markets set price ("get prices right"), end inflation ("macroeconomic stability"), privatize. (Chomsky 1999: 19-20).

Certain characteristics of neoliberalism have been summarized by Elizabeth Martinez and Arnoldo Garcia of the National Network for Immigrant and Refugee Rights, in their 
article published in CorpWatch (http://www.corpwatch.org/article.php?id=376). They write that,

The main points of neoliberalism include: 1 . The rule of the market. Liberating "free" enterprise or private enterprise from any bonds imposed by the government (the state) no matter how much social damage this causes. Greater openness to international trade and investment, as in NAFTA. Reduce wages by de-unionizing workers and eliminating workers' rights that had been won over many years of struggle. No more price controls. All in all, total freedom of movement for capital, goods, and services. To convince us this is good for us, they say "an unregulated market is the best way to increase economic growth, which will ultimately benefit everyone." It's like Reagan's "supply-side" and "trickle-down" economics - but somehow the wealth didn't trickle down very much; 2. Cutting back expenditures for social services like education and healthcare. Reducing the safety net for the poor, and even maintenance of roads, bridges, water supply - again in the name of reducing government's role. Of course, they don't oppose government subsidies and tax benefits for business; 3. Deregulation. Reduce government regulation of everything that could diminish profits, including protecting the environmental safety on the job; 4. Privatization. Sell state-owned enterprises, goods, and services to private investors. This includes banks, key industries, railroads, toll highways, electricity, schools, hospitals, and even fresh water. Although usually done in the name of greater efficiency, which is often needed, privatization has mainly had the effect of concentrating wealth even more in a few hands and making the public pay even more for its needs; 5 . Eliminating the concept of "the public good" or "community" and replacing it with "individual responsibility". Pressuring the poorest people in a society to find solutions to the lack of health care, education, and social security all by themselves - then blaming them, if they fail, as lazy." Economists who disagree with these perspectives would include, for example, Milton Friedman, who argues that government intervention prevents the market from regulating itself, and that fairness in economic trading is best achieved by removing "barriers" such as protectionist policies (e.g., Capitalism and Freedom, 1963). Hence Friedman is an example of an organic intellectual promoting neoliberal policies, and therefore supporting agreements such as GATS. Since these policies represent the dominant economic paradigm, the discourses supporting the paradigm are referred to as "hegemonic discourses". In contrast, economists such as Samir Amin (e.g., Capitalism in the Age of Globalization, 1997) argue that the neoliberal structural adjustment programs applied to the "third world" countries by the major economic institutions (International Monetary Fund, the World Bank, GATT-WTO) have had the following consequences: "a sharp increase in unemployment, a fall in the remuneration of work, an increase in food dependency, a grave deterioration of the environment, a deterioration in healthcare systems, a fall in admissions to educational institutions, a decline in the productivity capacity of many nations, the sabotage of democratic systems, and the continued growth of external debt. (Amin:13).

Amin's arguments exemplify a counter-hegemonic analysis of neoliberal global policies, and offer solutions sensitive to economic trading asymmetries arising through colonial histories.

3. I use the term "reform" here as a change, but not necessarily a change for the better. During the 1980's and 90's there existed in Canada a political party called "The Reform Party", which was one of the most aggressive in terms of advocating for neoliberal restructuring of the social welfare state. The term "reform" in Canada is therefore associated with neoliberal changes, and ultra-rightwing conservative ideologies such as: lobbying against same-sex marriage, and promoting a kind of Christian fundamentalist "family values" discourse antagonistic to many of the struggles of feminist and other progressive groups. In 2000 the Reform Party has merged with the Conservative Party, the new party now called "The Alliance Party". 
4. DeSequeira offers a detailed analysis of WTO/GATS text relevant to restructuring education as a consumer driven globalized service. As she notes: In 1998, a document elaborated by the WTO Secretariat on educational services was disclosed (WTO, September1998). Its contents not only pointed out the economic importance of education, mainly for countries that usually receive a large number of foreign students (USA, France, Germany, United Kingdom, Russian Federation, Japan, Australia, Canada, Belgium, and Switzerland) but also revealed the expected expenditure for education services in countries with a large school age population (from 5 to 29 years). It also highlighted changes that are taking place within the education sector. These include the reduction of public resources, which has been provoking a growing search for alternative sources of funding; and the adoption of business administration practices. This same text reveals the emergence of new institutions and forms of partnerships between public and private providers, mentioning the example of the West Governor's University in the USA, founded by 17 governments of the Western US, with private partners such as IBM, AT\&T, Cisco, Microsoft and Thomson. It clearly states that the aforementioned university does not employ any teachers or develop its own courses, but acquires academic contents from "faculty providers" employed by other public and private institutions. It reaches students through the Internet and other distance learning technologies (WTO, 1998, 5). This means that it functions as a virtual university: no faculties, no large buildings or campuses, nor students wandering around." (DeSequeira 2005, 12).

5. This is the strategy that has already been in place since the 1990's in Ontario when tuition fees for graduate, professional, and business programs were deregulated, and thirty percent of the additional fees set aside for financial assistance. In the Rae plan, institutions would decide individually how much of their revenues to set aside for financial assistance.

6. For those unfamiliar with Canadian politics, the province of Alberta, along with Ontario, have been among the first provinces to adopt an aggressive neoliberal approach to restructuring the higher education system. Alberta is known for its right-wing political culture, and is often compared to Texas in this respect.

7. Some of the differences between neoliberal and social democratic policies with regard to postsecondary education are examined in Magnusson (2000) Canadian higher education and citizenship in the context of state restructuring and globalization. The social democratic policies work toward strengthening the social welfare state; neoliberal policies work toward diminishing the social welfare state. 
136 Encounters/Encuentros/Rencontres 